\title{
An investigation of allergy in byssinosis: sensitization to cotton, hemp, flax and jute antigens
}

\author{
V. POPA, N. GAVRILESCU, N. PREDA, D. TECULESCU, \\ M. PLECIAS, AND M. CÎRSTEA \\ Department of Occupational Diseases, Hospital Colentina, Bucharest 10, Rumania
}

\begin{abstract}
Popa, V., Gavrilescu, N., Preda, N., Teculescu, D., Plecias, M., and Cîrstea, M. (1969). Brit. J. industr. Med., 26, 101-108. An investigation of allergy in byssinosis: sensitization to cotton, hemp, flax, and jute antigens. The authors investigated allergy to cotton, hemp, flax, and jute in $\mathbf{4 1}$ subjects with byssinosis. In contrast with immediate skin reactions, which were seldom observed, delayed reactions were nearly always present. The incidence of positive skin tests in byssinosis was similar to that observed in all textile workers. Inhalation tests with textile allergens were negative in all but four subjects who also had a concomitant bronchial asthma. Fifteen out of 31 subjects with byssinosis had positive inhalation tests to acetylcholine but only one of the 13 tested had a positive response to the inhalation of textile macerate. Haemagglutinating antibodies to low titres could be observed in byssinosis as well as in chronic bronchitis, in bronchial asthma, and in the general population. The significance of various types of antibodies existing in byssinosis is further discussed. The authors stress the need to standardize textile allergens.
\end{abstract}

At present there are two main hypotheses on the pathogenesis of byssinosis; one attributes byssinosis to an endotoxin-like action of textile dust (Pernis, Vigliani, Cavagna, and Finulli, 1961), and the other ascribes to textile dust a histamine-liberating action (Antweiler, 1961; Bouhuys, van Duyn, and van Lennep, 1961; Bouhuys and Lindell, 1961). Only a few investigators have claimed there to be an allergic pathogenesis (Prausnitz, 1936; GernezRieux, Voisin, Jacob, Corsin, and Lefebvre, 1962; Marchand, Voisin, and Werner, 1963; Werner, 1956; Massoud and Taylor, 1964). Although stimulating, their works do not furnish conclusive arguments for an allergic mechanism in byssinosis because (1) in more detailed research Furness and Maitland (1952) could find no evidence that allergy is a mechanism of action in byssinosis; (2) allergy was investigated only in cotton workers' byssinosis, although byssinosis has also been reported in hemp and flax factories (Mair, Smith, Wilson, and Lockhart, 1960; Smith, Lockhart, Mair, and Wilson, 1962); and (3) in spite of the multiple sensitization pathways existing in allergic diseases (Gell and Coombs, 1963), only some of them have been investigated so far.

The present authors considered that, for a more detailed evaluation of the role of allergy in byssinosis, the following conditions have to be fulfilled: (1) the study should comprise subjects with byssinosis acquired not only in cotton but also in hemp, flax, and jute factories; (2) the study should compare sensitization to textile dust observed in byssinosis with sensitization to the same allergens observed in other chest diseases.

The preliminary results of our investigation have already been reported (Popa, Gavrilescu, Preda, and Teculescu, 1966; Preda, Gavrilescu, Popa, Teculescu, and Cîrstea, 1965; Preda, Gavrilescu, Popa, and Teculescu, 1966). 


\section{Material and methods}

\section{Subjects}

There were two groups of subjects:

Group 1 included some of the workers examined in two factories during a mass survey for byssinosis, chronic bronchitis, and bronchial asthma (Preda et al., 1965), 82 subjects from a cotton factory (factory $A$ ) and 83 subjects from a hemp, flax, and jute factory (factory B). Each group of subjects comprised (1) all subjects with byssinosis, bronchial asthma, and chronic bronchitis from the card room, blowing room, and hackling room; (2) half of the subjects with 'respiratory irritation symptoms'1 and half of the asymptomatic subjects from the same work rooms; these subjects were selected at random (all workers presenting the above symptoms who worked, at the time of the investigation, in the morning shift).

Group 2 for a more detailed study, included all 19 subjects with byssinosis attending the in-patient and outpatient departments of occupational medicine between 1 January 1965 and 1 August 1967 and all the 22 byssinosis cases from the mass survey.

The diagnosis of byssinosis was made on the criteria suggested by Schilling (1956) and Schilling, Vigliani, Lammers, Valic, and Gilson (1964).

\section{Material}

Allergens were prepared according to Gradwohl's method (1948), slightly modified (Plecias, 1966) from the following material: cotton (originating from different rooms in the factory: blowing room-allergen 1 ; preparation room-allergen 2; hackling room-allergen 3); hemp (hemp bundle-allergen 4, hemp fibreallergen 5); flax (flax bundle-allergen 6, flax fibreallergen 7); and jute (jute fibre-allergen 8).

A crude extract (macerate) from every textile fibre handled in the factories was prepared according to the method of Bouhuys and Lindell (1961).

\section{Methods}

Intradermal tests were made with allergens but not with textile macerate. Our allergens were employed in a concentration of 100 protein nitrogen units (P.N.U.) per millilitre. Forty subjects not engaged in processing textile fibres served as a control group for skin tests with these allergens. The 82 subjects from cotton factory $A$ were also skin tested to hemp, flax, and jute in order to evaluate the antigenic relationship of the textile allergens. Unfortunately, a similar study was not possible in factory $B$ with cotton allergens.

Thirty-nine subjects with byssinosis were submitted to inhalation tests with the authors' allergens. For all subjects, nebulization was made with a concentration of 1,000 P.N.U./ml.; eight subjects with an equivocal spirographic response (a fall of F.E.V.1.0 of 8 to $9 \%$ ) performed a second inhalation test with 10,000 P.N.U./ $\mathrm{ml}$. after two days. Thirteen of the 39 workers with

${ }^{1}$ Respiratory irritation symptoms $=$ cough - occasionally also sneezing and nasal pruritus-appearing only at the place of work, every day of the week (with no Monday accentuation) and aggravated by any increase in dust concentration (e.g., cleaning of machines). byssinosis also performed inhalation tests with a macerate extracted from the textile material they handled.

Inhalation tests were conducted as follows: substances were nebulized for 5 minutes through an open-circuit nebulizer with an output of $0.2 \mathrm{ml} . / \mathrm{min}$.; nebulization was preceded and followed (at 30 minutes, 60 minutes, and immediately after onset of eventual asthma attacks) by a clinical pulmonary examination and a spirographic recording of vital capacity (V.C.) and forced expiratory volume in the first second (F.E.V.1.0). At least three similar records of V.C. and F.E.V.1.0 were obtained; in measuring the latter, the Koy convention recommended by the American College of Chest Physicians (1963) was applied. The highest of the three values was taken for both V.C. and F.E.V.1.0. The tests were considered to be positive when there was at least a $10 \%$ decrease of F.E.V.1.0 and, at the same time, clinical signs of bronchospasm (dyspnoea, wheezing, and eventually râles).

Equivocal (dissociation of clinical and spirographic responses) as well as positive tests were repeated. In order to assess the irritant power of textile macerate we used, as a control group, six asthmatic subjects, three sensitized to a textile allergen and three sensitized to other allergens.

In 31 subjects with byssinosis (29 also performing allergen inhalation tests and two not carrying out such tests) a $1 \%$ acetylcholine solution was nebulized for 3 minutes with the same nebulizer and with the same recording method as above.

Circulating antibodies were investigated by two methods-agar double diffusion (Ouchterlony, 1962) and tanned red cell agglutination (Borduas and Grabar, 1953).

Precipitating antibodies were investigated in 20 cases of byssinosis (10 from factory $A$ and 10 from factory $B$ ) with our allergens (10,000 P.N.U./ml.) and in six subjects with byssinosis from each factory with undiluted textile macerate as antigen.

Haemagglutinating antibodies were determined in 34 sera, using as the antigen all our 8 allergens; 14 sera were from workers with byssinosis (7 each from factories A and B), 8 sera (4 from each factory) from patients with chronic asthmatic bronchitis, 4 sera from asthmatics ( 2 from each factory), and 8 sera from normal subjects. ${ }^{1}$

Histamine-releasing activity was investigated for all our allergens, at a concentration of 1,000 P.N.U./ml., using Antweiler's (1961) technique.

For statistical analysis we used the $\chi^{2}$ method; $P<0.01$ was considered statistically significant.

\section{Results}

The incidence of positive reactions to the intradermal injection of our textile allergens is shown in Table 1 for the cotton mill and in Table 2 for the hemp, flax, and jute mill.

Table 3 illustrates the results obtained in 66 subjects from factory $A$ and in 70 subjects from factory $\mathbf{B}$ with non-allergic respiratory disease, skintested to hemp, flax, and jute allergens.

${ }^{1}$ Normal subjects $=$ subjects with no clinically overt disease and without any occupational contact with textile dust. 
TABLE 1

Intradermal Reactions to Cotton Allergens in Normal Subjects not Exposed to Textile DUST AND IN WORKERS FROM A COTTON FACTORY

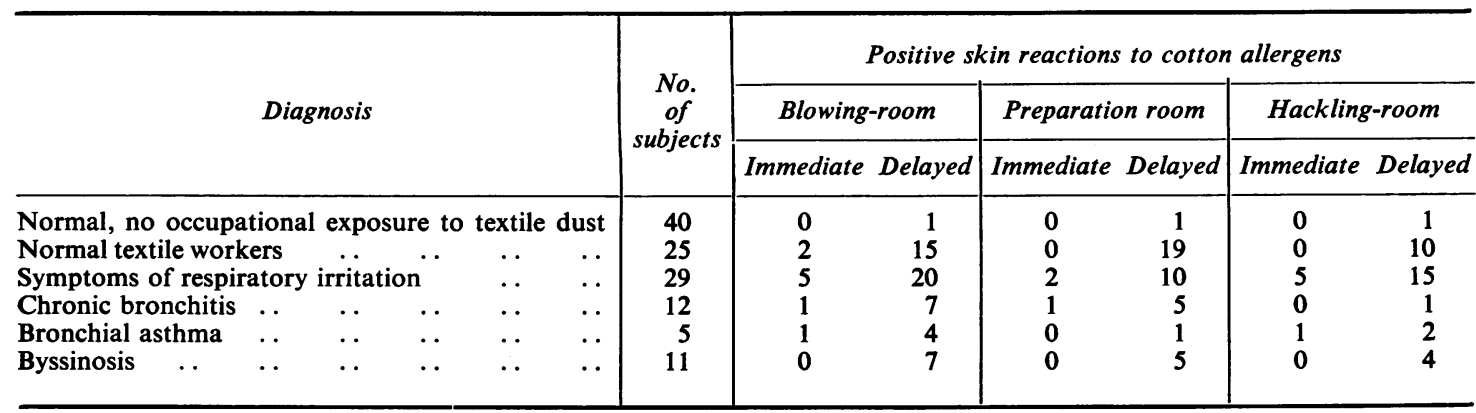

TABLE 2

Intradermal Reactions to Hemp, Flax, and Jute in Normal Subjects not Exposed to Textile Dust and in WORKERS From a HeMP, FlaX, and JUTE FACTORY

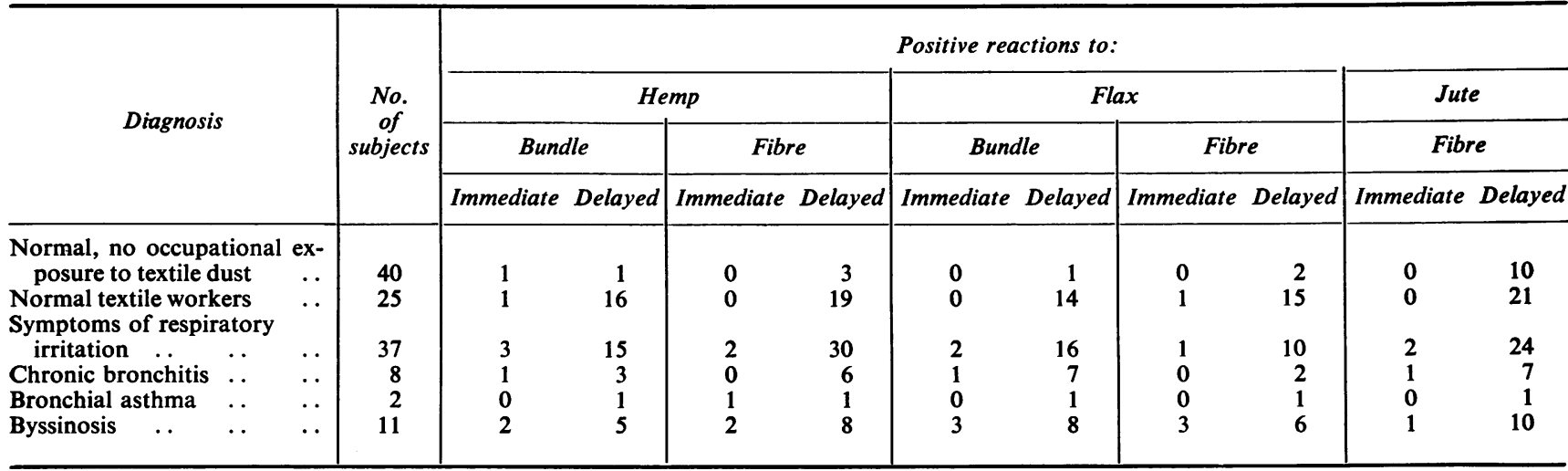

TABLE 3

Intradermal Reactions to Hemp, Flax, and Jute in a Cotton Factory, in a Hemp, Flax, and Jute Factory, AND IN A CONTROL Group

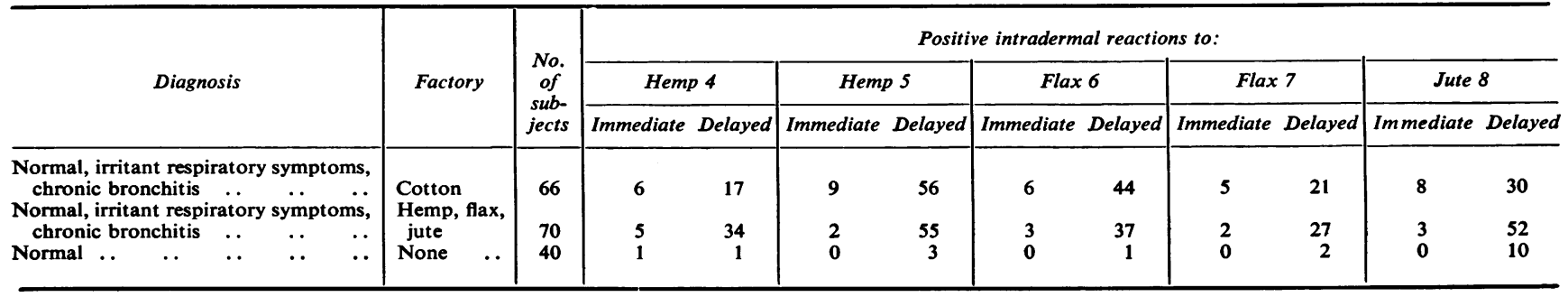


TABLE 4

Positive Skin Tests in Byssinotic SubJects from Cotton Factories

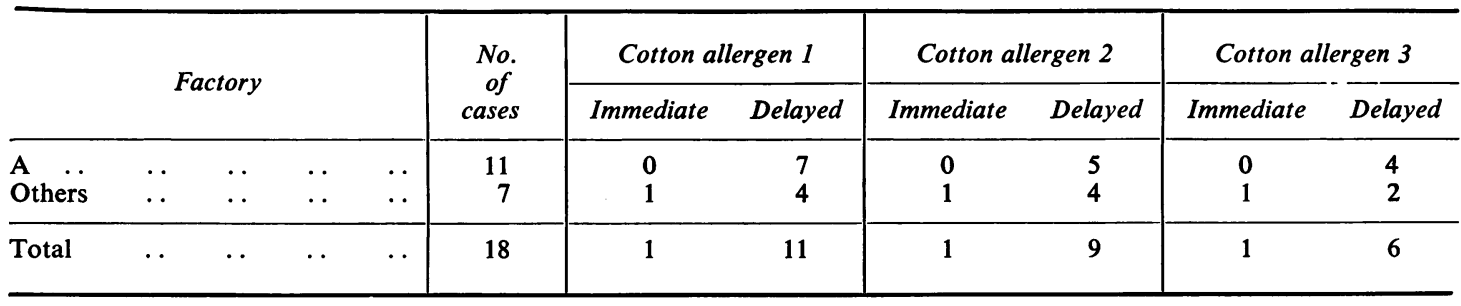

TABLE 5

Positive Skin Tests in Byssinotic Subjects from Hemp, Flax, and Jute Factories

\begin{tabular}{|c|c|c|c|c|c|c|c|c|c|c|c|}
\hline \multirow{2}{*}{ Factory } & \multirow{2}{*}{$\begin{array}{c}\text { No. } \\
\text { of } \\
\text { cases }\end{array}$} & \multicolumn{2}{|c|}{ Hemp allergen 4} & \multicolumn{2}{|c|}{ Hemp allergen 5} & \multicolumn{2}{|c|}{ Flax allergen 6} & \multicolumn{2}{|c|}{ Flax allergen 7} & \multicolumn{2}{|c|}{ Jute allergen 8} \\
\hline & & Immediate & Delayed & Immediate & Delayed & Immediate & Delayed & Immediate & Delayed & Immediate & Delayed \\
\hline 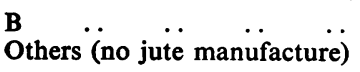 & $\begin{array}{l}11 \\
12\end{array}$ & $\begin{array}{l}2 \\
1\end{array}$ & $\begin{array}{l}5 \\
6\end{array}$ & $\begin{array}{l}2 \\
3\end{array}$ & $\begin{array}{l}8 \\
8\end{array}$ & $\begin{array}{l}3 \\
3\end{array}$ & $\begin{array}{l}8 \\
9\end{array}$ & $\begin{array}{l}3 \\
2\end{array}$ & $\begin{array}{l}6 \\
7\end{array}$ & 1 & 10 \\
\hline Total ... & 23 & 3 & 11 & 5 & 16 & 6 & 17 & 5 & 13 & 1 & 10 \\
\hline
\end{tabular}

\section{Allergic response in subjects with byssinosis}

Skin tests Delayed reaction (a nodule of at least $5 \mathrm{~mm}$. at 24 hours, subsiding at 48 or 72 hours) occurred in subjects from cotton factories (Table 4) as well as in subjects from hemp, flax, and jute factories (Table 5), according to the pattern described above. Immediate reactions (a wheal of at least $8 \mathrm{~mm}$. at 30 minutes) were recorded in subjects from both groups of factories. Two subjects with 'cotton byssinosis'1 and four subjects with 'hemp, flax, and jute byssinosis' ${ }^{1}$ had no positive reactions to the tests.

Inhalation tests Positive responses to inhalation tests to textile allergens (Table 6) were obtained in four of the 39 subjects with byssinosis. All four had grade II byssinosis. Three subjects worked in factory B; two had positive tests to hemp and one to flax. One subject worked in factory A and evidently had a positive test to cotton. All these subjects also had symptoms suggestive of bronchial asthma. The concentration of the allergens evoking a positive response was 1,000 P.N.U./ml.

Textile macerate produced only one positive

${ }^{1 ' C o t t o n ~ b y s s i n o s i s ' ~ i s ~ b y s s i n o s i s ~ o c c u r r i n g ~ i n ~ w o r k e r s ~ f r o m ~}$ a cotton factory. 'Hemp, flax, and jute byssinosis' is byssinosis occurring in workers from a hemp, flax, and jute factory. No other distinction between these two types of byssinosis is meant.
TABLE 6

Inhalation Tests with TeXtile Allergens

\begin{tabular}{ll|c|cc}
\hline \multirow{2}{*}{ Factory } & & \multirow{2}{*}{$\begin{array}{c}\text { Grade of } \\
\text { byssinosis }\end{array}$} & \multicolumn{2}{c}{ Inhalation tests } \\
\cline { 3 - 5 } & & Positive & Negative \\
\hline Cotton &.. & I & 0 & 7 \\
& & II & 1 & 4 \\
\hline Hemp, flax, and jute.. & I & 0 & 12 \\
& II & 3 & 12 \\
\hline & Total & 4 & 35 \\
\hline
\end{tabular}

TABLE 7

Inhalation Tests With TeXtile Macerate

\begin{tabular}{ll|c|cc}
\hline \multirow{2}{*}{ Factory } & & \multirow{2}{*}{$\begin{array}{c}\text { Grade of } \\
\text { byssinosis }\end{array}$} & \multicolumn{2}{c}{ Inhalation tests } \\
\cline { 3 - 5 } & & Positive & Negative \\
\hline Cotton &.. & I & 0 & 3 \\
& II & 0 & 2 \\
\hline Hemp, flax, and jute.. & I & 1 & 2 \\
& II & 0 & 5 \\
\hline
\end{tabular}


TABLE 8

INHALATION Tests With ACETylChOline

\begin{tabular}{ll|c|cc}
\hline \multicolumn{2}{c|}{ Factory } & \multirow{2}{*}{$\begin{array}{c}\text { Grade of } \\
\text { byssinosis }\end{array}$} & \multicolumn{2}{c}{ Inhalation tests } \\
\cline { 3 - 5 } & & I & 1 & 3 \\
\hline Cotton &. & II & 1 & 3 \\
\hline Hemp, flax, and jute.. & I & 1 & Negative \\
\hline & II & 12 & 3 \\
\hline
\end{tabular}

reaction (Table 7). All six asthmatics forming the control group had positive reactions.

The results of inhalation tests with acetylcholine are shown in Table 8. The correlation of acetylcholine inhalation tests with allergen inhalation tests is shown in Fig. 1 and with textile macerate inhalation tests in Figure 2.

Circulating antibodies It was impossible to find precipitating antibodies to any textile allergen or textile macerate by the agar double diffusion method.

All the subjects investigated by the tanned red cell agglutination method (Table 9) - with byssinosis, chronic asthmatic bronchitis, and bronchial asthma, and normal subjects-had circulating antibodies against every type of allergen used. Among these diseases there were no significant differences in agglutination titres for any allergen.

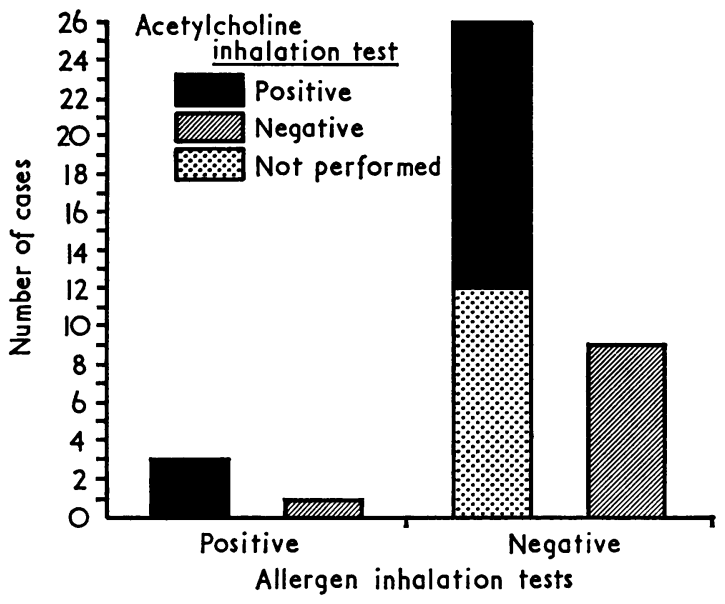

FIG. 1. Relationship between allergen inhalation tests and acetylcholine inhalation tests.

Histamine-liberating activity This was absent from all the textile allergens.

\section{Discussion}

Positive skin tests to textile allergens in cotton and in hemp, flax, and jute factories

Immediate reactions A statistical approach is difficult for immediate reactions in subjects from

TABLE 9

Circulating Antibodies against Cotton, Hemp, Flax, and Jute Antigens

\begin{tabular}{|c|c|c|c|c|c|c|c|c|c|c|c|}
\hline \multicolumn{2}{|l|}{ Diagnosis } & \multirow{2}{*}{$\begin{array}{c}\text { Factory } \\
\text { A } \\
\text { B }\end{array}$} & \multirow{2}{*}{$\begin{array}{c}\begin{array}{c}\text { No. } \\
\text { of } \\
\text { cases }\end{array} \\
7 \\
7\end{array}$} & \multicolumn{8}{|c|}{ Titre of antibodies to textile allergens: } \\
\hline Byssinosis & . & & & $\begin{array}{c}1: 8-1: 128 \\
(6) \\
1: 16-1: 64 \\
(5)\end{array}$ & $\begin{array}{c}1: 8-1: 128 \\
(3) \\
1: 8-1: 64 \\
(3)\end{array}$ & $\begin{array}{c}1: 16-1: 128 \\
(6) \\
1: 8-1: 128 \\
(5)\end{array}$ & $\begin{array}{c}1: 16-1: 64 \\
(4) \\
1: 8-1: 64 \\
(3)\end{array}$ & $\begin{array}{c}1: 16-1: 128 \\
(5) \\
1: 8-1: 64 \\
(6)\end{array}$ & $\begin{array}{c}1: 32-1: 64 \\
(7) \\
1: 16-1: 128 \\
(6)\end{array}$ & $\begin{array}{c}1: 8-1: 64 \\
(4) \\
1: 8-1: 32 \\
(3)\end{array}$ & $\begin{array}{c}1: 8-1: 64 \\
(4) \\
1: 8-1: 64 \\
(2)\end{array}$ \\
\hline $\begin{array}{l}\text { Chronic asthmatic } \\
\text { bronchitis }\end{array}$ & $\cdots$ & $\begin{array}{l}\mathbf{A} \\
\mathbf{B}\end{array}$ & $\begin{array}{l}4 \\
4\end{array}$ & $\begin{array}{c}1: 16-1: 64 \\
(2) \\
1: 16-1: 64 \\
(2)\end{array}$ & $\begin{array}{c}1: 32-1: 128 \\
(2) \\
1: 16-1: 64 \\
(3)\end{array}$ & $\begin{array}{c}1: 16-1: 128 \\
(3) \\
1: 16-1: 64 \\
\text { (3) }\end{array}$ & $\begin{array}{c}1: 8-1: 64 \\
(3) \\
1: 8-1: 32 \\
(1)\end{array}$ & $\begin{array}{c}1: 8-1: 16 \\
(0) \\
1: 8-1: 64 \\
(2)\end{array}$ & $\begin{array}{c}1: 16-1: 64 \\
(3) \\
1: 32-1: 128 \\
\text { (4) }\end{array}$ & $\begin{array}{c}1: 16-1: 32 \\
(3) \\
1: 16-1: 32 \\
(2)\end{array}$ & $\begin{array}{c}1: 18-1: 64 \\
\quad(1) \\
1: 8-1: 64 \\
\text { (1) }\end{array}$ \\
\hline Bronchial asthma & .. & $\begin{array}{l}\mathbf{A} \\
\mathbf{B}\end{array}$ & $\begin{array}{l}2 \\
2\end{array}$ & $\begin{array}{c}1: 64-1: 254 \\
(2) \\
1: 8-1: 16 \\
(0)\end{array}$ & $\begin{array}{c}1: 32-1: 128 \\
(2) \\
1: 32 \\
\text { (2) }\end{array}$ & $\begin{array}{c}1: 16-1: 32 \\
\text { (1) } \\
1: 64 \\
\text { (2) }\end{array}$ & $\begin{array}{c}1: 32-1: 64 \\
\text { (2) } \\
1: 32-1: 128 \\
\text { (2) }\end{array}$ & $\begin{array}{c}1: 8-1: 16 \\
(0) \\
1: 16-1: 32 \\
(1)\end{array}$ & $\begin{array}{c}1: 64 \\
(2) \\
1: 8-1: 64 \\
\quad(1)\end{array}$ & $\begin{array}{c}1: 16-1: 128 \\
(1) \\
1: 16-1: 64 \\
(1)\end{array}$ & $\begin{array}{c}1: 8-1: 128 \\
(1) \\
1: 32 \\
(2)\end{array}$ \\
\hline Control subjects .. & .. & None & 8 & $\begin{array}{c}1: 4-1: 128 \\
\text { (3) }\end{array}$ & $\begin{array}{c}1: 8-1: 128 \\
(6)\end{array}$ & $\begin{array}{c}1: 8-1: 128 \\
\text { (3) }\end{array}$ & $\begin{array}{c}1: 8-1: 128 \\
\text { (4) }\end{array}$ & $\begin{array}{c}1: 8-1: 128 \\
(6)\end{array}$ & $\begin{array}{c}1: 8-1: 128 \\
(5)\end{array}$ & $\begin{array}{c}1: 16-1: 128 \\
\text { (4) }\end{array}$ & $\begin{array}{c}1: 8-1: 128 \\
\text { (3) }\end{array}$ \\
\hline
\end{tabular}

Number of subjects with a titre higher than 1:16 in parentheses. 


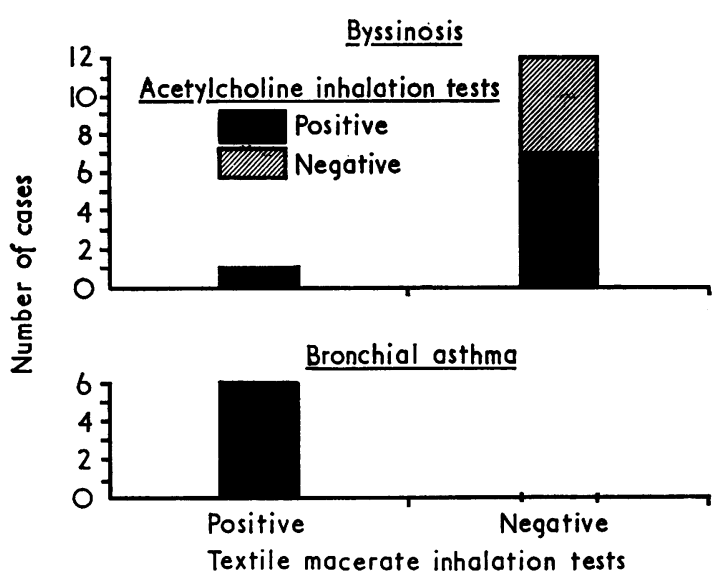

FIG. 2. Relationship between textile macerate inhalation tests and acetylcholine inhalation tests.

both factories A and B. In 'cotton byssinosis', immediate reactions are usually absent. In 'hemp, flax, and jute byssinosis', they may be present. Cayton, Furness, and Maitland (1952) claimed that their control group had a higher incidence of immediate reactions to cotton allergens $(40 \%)$ than had the textile workers $(27 \%)$ and subjects with byssinosis $(28 \%)$. Our results therefore differ from those obtained by Cayton and his colleagues; the explanation may be the different allergen extraction.

Immediate reactions to textile allergens were noticed in many subjects with no allergic complaints; thus, immediate reactions seemed to represent a 'latent allergy' (Hansen, 1957). Allergen fractions involved in immediate 'latent allergy' were not the same in those eliciting delayed reactions. From Tables 1 and 2 it is obvious that for any allergen, whatever the group of subjects, the incidence of immediate reactions is not exactly the same as that of delayed ones.

Delayed reactions In asymptomatic textile workers the incidence of delayed hypersensitivity was higher (statistically significant) than in normal subjects. Compared with the former, the subjects with byssinosis, bronchial asthma, chronic bronchitis, and 'respiratory irritation symptoms' had a similar incidence of delayed reactions (the differences are not statistically significant). This fact was observed for every allergen in both factories investigated. The skin reaction pattern is thus in agreement with the findings of Cayton and his colleagues (1952): positive delayed reactions occurred in $100 \%$ of their cotton workers and in $90 \%$ of their normal subjects. The incidence of positive delayed reactions reported by Cayton and his colleagues (1952) and by Maitland (1956) is higher than ours and may be due to the different methods of extracting allergens.
Perhaps the delayed reactions to textile allergens also express a 'latent allergy', as their incidence is similar in subjects with various non-allergic respiratory diseases. But 'latent allergy' to pneumallergens is usually of the immediate type, in contrast to that due to bacteria or fungi, which is of the delayed type. In textile dust there are numerous bacteria and fungi (Furness and Maitland, 1952). A further report (Gavrilescu, Popa, Preda, Teculescu, Avram, and Nicolau, 1969) will exclude fungal allergy and so a bacterial delayed reaction becomes a strong possibility.

Antigenic relationship between the textile fibres As Table 3 shows, workers from a cotton factory (factory A) have a higher incidence of positive skin tests to hemp, flax, and jute than have normal subjects but a similar (statistically) incidence to that observed in normal textile workers of factory B. It follows that sensitization to cotton is accompanied by a concomitant sensitization to hemp, flax, and jute; therefore common antigenic fractions for cotton, hemp, flax, and jute seem to exist.

A comparison of the incidence of positive reactions elicited by the three cotton allergens (allergen 1, 2, and 3 ) in one group of patients indicates that whatever the group, each cotton allergen gives a distinct percentage of positive reactions. The same observation is also valid for hemp and flax allergens, hemp bundle allergen versus hemp fibre allergen, as well as flax bundle allergen versus flax fibre allergen; all gave different percentages of positive reactions in every group investigated. The differences observed are not statistically significant; thus a textile fibre generally preserves its main allergens throughout the factory process. The above-mentioned differences may be explained by some addition or removal of allergen during processing; but these allergenic changes are minor and are detected only in some subjects.

\section{Allergic response in subjects with byssinosis}

Intradermal tests There were no immediate reactions in subjects with 'cotton byssinosis' in factory $\mathrm{A}$, and only very rarely in the other factories. Immediate reactions may also be present in subjects with 'hemp, flax, and jute byssinosis' but are rather uncommon. Most cases of byssinosis do not have positive immediate skin tests, a fact difficult to reconcile with a pathogenic hypothesis claiming a sensitization mediated by a reaginic antibody.

Delayed reactions, though more frequent than immediate reactions, are not a constant feature of bysinnosis of any type (six subjects had no delayed reactions to our textile allergens). Our findings are similar to those of Gernez-Rieux and his co-workers (1962) and Marchand and his co-workers (1963), 
who found that only $40 \%$ of workers with byssinosis had positive reactions to cotton.

Inhalation tests with textile allergens Positive inhalation tests with allergens strongly support sensitization as the mechanism in respiratory diseases. ${ }^{1}$ We found only four positive inhalation tests in byssinotics; these tests are a characteristic feature of allergic bronchial asthma. The presence of positive inhalation tests as well as a clinical history and physical examination suggestive of bronchial asthma demonstrate that among the workers with byssinosis there are some subjects with a superimposed bronchial allergy.

Gernez-Rieux and his co-workers (1962) and Marchand and his co-workers (1963) claimed that one-third of their 25 cases with byssinosis had positive inhalation tests to cotton. Voisin, Jacob, Furon, and Lefebvre (1966) reported that 11 of their 62 subjects with 'cotton byssinosis' reacted to inhalation tests with cotton. Even accepting this high percentage of bronchial reactions, it is obvious that sensitization does not play a constant and fundamental role in the pathogenesis of byssinosis.

Inhalation tests with textile macerate $A$ positive response to the inhalation of textile macerate was always recorded in bronchial asthma, irrespective of its aetiology. Bouhuys and his co-workers (1961) also obtained positive results in asthmatic patients. An irritant, non-specific action of the macerate should therefore be considered and suggests that the macerate may be unsuitable for the investigation of allergy.

In byssinosis, provocation tests with textile macerate yielded, with one exception, negative responses. Thus it should not be used in the diagnosis of byssinosis. Bouhuys and his co-workers (1961), also, did not recommend such tests for diagnostic purposes. Negative tests were noted in subjects with or without bronchial cholinergic hyperreactivity; a positive reaction appeared in a subject with a positive acetylcholine inhalation test which suggests that individuals with cholinergic hyperreactivity may be more prone to positive inhalation tests with textile macerate than are those without.

In three subjects with byssinosis and asthma, the unpleasant smell of textile macerate prevented us from using it for inhalation tests. One subject with byssinosis and asthma had a negative inhalation test to the macerate prepared from the same textile fibre to which she was sensitized. This rather surprising phenomenon could be due to two factors: (1) a higher threshold for textile macerate irritative action than is common in bronchial asthma, and

${ }^{1}$ As we used diluted allergens, no assessment could be made of the allergic mechanism mediated by precipitating antibodies (Pepys, 1960).
(2) inefficient extraction of textile allergen(s) during preparation of the macerate.

Inhalation tests with acetylcholine These tests were performed by a qualitative method, without quantitative evaluation of cholinergic hyperreactivity. The method has yielded a $97 \%$ positive response in bronchial asthma and a $10 \%$ response in chronic asthmatic bronchitis (Popa, Gavrilescu, Teculescu, and Stanescu, 1967).

Fifteen of our 31 cases of byssinosis had cholinergic hyperreactivity. In 'hemp, flax, and jute byssinosis', positive acetylcholine tests were more frequent in grade II than in grade I (statistically significant). In 'cotton byssinosis', the small number of subjects did not allow statistical analysis. Cholinergic hyperreactivity of the bronchi was present in three subjects with byssinosis and asthma; in one subject the acetylcholine inhalation test could not be performed.

The high incidence of positive acetylcholine inhalation tests in byssinosis was emphasized by Verbeke (1963), Verbeke, Callens, and Vermeire (1963), and Verbeke, Tasson, and Verbeke (1964) who found 10 positive tests in 13 cases.

Histamine inhalation tests are sometimes positive in byssinosis (Bouhuys, 1967; Massoud, Altounyan, Howell, and Lane, 1967); they are always positive in grade II byssinosis if chronic bronchitis coexists (Massoud et al., 1967). From the available data, occasional cholinergic and histamine bronchial hyperreactivity in byssinosis is more often an expression of chronic bronchitis than of an allergic process.

The histamine-releasing activity of our textile fibre allergens was zero. Therefore the skin and bronchial reactions provoked by these allergens were not due to histamine-liberating substances.

Circulating antibodies The absence of precipitating antibodies against textile macerate antigens or against the whole textile plant allergen of the authors is not at variance with the findings of Massoud and Taylor (1964). These authors detected precipitating antibodies against the cotton flower receptacle; other parts did not reveal any precipitating antibody.

All the subjects (normal subjects and workers with byssinosis, bronchial asthma, and chronic asthmatic bronchitis) investigated by the tanned red cell agglutination method had antibodies against our allergens; their titres were very low and quite similar. Their presence in all these cases proves the immunogenic capacity of textile fibres but shows that they lack any pathogenic significance.

Finally, we summarize the various antibody responses that might be elicited by the multiple antigens in cotton, hemp, flax, and jute. Circulating antibodies are of several types: (1) reagins (in 
bronchial asthma due to sensitization to textile dust); (2) skin-sensitizing antibodies (positive immediate reactions in subjects having no clinical sign of allergy to textile dust-latent allergy); (3) circulating antibodies not skin sensitizing (haemagglutinating antibodies in subjects lacking immediate skin tests); and (4) precipitating antibodies (to cotton flower receptacle (Massoud and Taylor, 1964)).

As regards their specificity, both circulating antibodies and delayed hypersensitivity may be strictly specific or cross-reacting with other textile allergens. Some of the eliciting antigens are from the textile fibre itself, and others are part of its contaminants (bacteria, fungi, and textile flower residues).

In byssinosis, there are many antibodies against textile dust antigens; most, if not all, have no pathogenic significance.

The authors gratefully acknowledge the technical assistance given by Miss Maria Nicolae and Mrs. Aurelia Kishkanou.

\section{References}

American College of Chest Physicians Committee on Pulmonary Physiology (1963). Clinical spirometry. Dis. Chest, 43, 214-219.

Antweiler, H. (1960). Observations about a histamine liberating substance in cotton dust. Ann. occup. Hyg., 2, 152-156.

(1961). Histamine liberation by cotton dust extracts: evidence against its causation by bacterial endotoxins. Brit. J. industr. Med., $18,130-132$.

Borduas, A. G., and Grabar, P. (1953). L'bśmagglutination passive dans la recherche des anticorps antiprotéiques. Ann. Inst. Pasteur, 84, 903-923.

Bouhuys, A. (1967). Response to inhaled histamine in bronchial asthma and in byssinosis. Amer. Rev. resp. Dis., 95, 89-93.

-, Duyn, J. van., and Lennep, H. J. van. (1961). Byssinosis in flax workers. Arch. environm. Hith, 3, 499-509.

-, and Lindell, S. E. (1961). Release of histamine by cotton dust extracts from human lung tissue in vitro. Experientia (Basel), 17, 211-212.

Cayton, H. R., Furness, G., and Maitland, H. B. (1952). Studies on cotton dust in relation to byssinosis. Part II. Skin tests for allergy with extracts of cotton dust. Brit. J. industr. Med., 9, 186-196.

Furness, G., and Maitland, H. B. (1952). Studies on cotton dust in relation to byssinosis. Part I: Bacteria and fungi in cotton dust. Ibid., 9, 138-145.

Gavrilescu, N., Popa, V., Preda, N., Teculescu, D., Avram, M., and Nicolau, G. (1969). Allergy to house dust, bacteria and fungi in byssinosis. (To be published.)

Gell, P. G., and Coombs, R. R. A. (1963). Clinical Aspects of Immunology. Blackwell Scientific Publications, Oxford.

Gernez-Rieux, C., Voisin, C., Jacob, M., Corsin, L., and Lefebvre, J. (1962). Enquête allergologique chez 40 ouvriers de filature de coton souffrant de troubles dyspnéiques du travail. Poumon, 18, 651-657.

Gradwohl, R. B. H. (1948). Clinical Laboratory Methods and Diagnosis. A Textbook on Laboratory Procedures, with their Interpretation, 4 th ed. C. V. Mosby, St. Louis.

Hansen, K. (1957). Allergie, 3rd ed. G. Thieme, Stuttgart.
Mair, A., Smith, D. H., Wilson, W. A., and Lockhart, W. (1960). Dust diseases in Dundee textile workers. Brit. J. industr. Med., 17, 272-278.

Maitland, H. B. (1956). Recherches sur le rôle de l'allergie aux poussières de coton dans la pathogénie de la byssinose. Rev. méd. Liège, 11, 323-334.

Marchand, M., Voisin, C., and Werner, C. (1963). Die heutige Lage der Byssinose in Frankreich. Arztl. Prax., 41, 2243-2244.

Massoud, A., and Taylor, G. (1964). Byssinosis: antibody to cotton antigens in normal subjects and in cotton card-room workers. Lancet, 2, 607-610.

- Altounyan, R. E. C., Howell, J. B. L., and Lane, R. E. (1967) Effects of histamine aerosol in byssinotic subjects. Brit. J. industr. Med., 24, 38-40.

Ouchterlony, Ő. (1962). Diffusion-in-gel methods for immunological analysis. In Progr. Allergy., 6, 30-154.

Pepys, J. (1960). The role of human precipitins to common fungal antigens in allergic reactions. Acta allerg. (Kbh.), 15, suppl. 7, pp. 108-111.

Pernis, B., Vigliani, E. C., Cavagna, C., and Finulli, M. (1961). The role of bacterial endotoxins in occupational diseases caused by inhaling vegetable dusts. Brit. J. industr. Med., 18, 120-129.

Plecias, M. (1966). Prepararea in laborator a unor alergene. Igiena, $15,495$.

Popa, V., Gavrilescu, N., Preda, N., and Teculescu, D. (1966). Recherches sur la pathogénie de la byssinose. In Proceedings of the $X V$ International Congress of Occupational Health, Vienna. 1966, vol. 3, 295-298. (Paper BXV-8.)

__ Teculescu, D., and Stanescu, D. (1967). Symposium Internationale Allergologicum, Prague.

-, Teculescu, D., Stanescu, D., and Gavrilescu, N. (1968). The value of inhalation tests in perennial bronchial asthma. J. Allergy, 42, 130-139.

Prausnitz, C. (1936). Investigations on respiratory dust disease in operatives in the cotton industry. Spec. Rep. Ser. med. Res. Coun., London. No. 212.

Preda, N., Gavrilescu, N., Popa, V., and Teculescu, D., (1966). Klinische Aspekte der durch pflanzlichen Textilstaub hervorgerufenen Erkrankungen des Atmungsapparat. In Proceedings of the XV International Congress on Occupational Health, Vienna, vol. 3, pp. 287-290. (Paper B XV-4.)

- _ - and Cîrstea, R. (1965). Diseases of the respiratory apparatus in workers of the textile industry. Stud. and Res. Work's Hyg. Work Security, pp. 253-290, Editura Medicală, Bucharest.

Schilling, R. S. F. (1956). Byssinosis in cotton and other textile workers. Lancet, 2, 261-265 and 319-324.

_, Vigliani, E. C., Lammers, B., Valic, F., and Gilson, J. C. (1964). Report on a Conference on Byssinosis. In Proc. XIV int. Congr. occup. Hlth, Madrid, 1963, Vol. 2, [Excerpta Medica, Int. Congr. Ser. No. 62], pp. 137-145.

Smith, D. H., Lockhart, W., Mair, A., and Wilson. W. A. (1962) Flax workers' byssinosis in East Scotland. Scot. med. J., 7, 201-211.

Verbeke, R. (1963). Zur Pathogenese der Byssinose. Arztl. Prax., 41, 2244-2245.

_, Callens, L., and Vermeire, P. (1963). La fièvre de filature et la byssinose. Facteurs étiologiques et pathogénie. Bronches, 13, 246-253.

- Tasson, J., and Verbeke, J. (1964). Onderzoek naar de pathogenese van de byssinose. Acta tuberc. pneumol. belg., 55, 525-34.

Voisin, C., Jacob, M., Furon, D., and Lefebvre, J. (1966). Aspects cliniques et allergologiques des manifestations asthmatiques observées chez 114 ouvriers de filatures de coton. Poumon, 22, 529-538.

Werner, G. C. (1956). De la bronchiolite oedémateuse allergique; essai statistique sur l'asthme des poussières textiles végétales. Arch. mal. profes., Par., 16, 27-45.

Received for publication January 9, 1968. 